\title{
ANALISIS PERBANDINGAN 4 MAZHAB TENTANG PERNIKAHAN DALAM ISLAM
}

\author{
Umi Hani \\ E-mail: Umihani@gmail.com \\ Fakultas Studi Islam Universitas Islam Kalimantan MAB Banjarmasin
}

\begin{abstract}
This study aims to analyze: 1) the Islamic view of the marriages, 2) a comparison of 4 schools about the marriages of marriage in Islam. Type of juridical-normative research or doctrinal legal research. Library research, namely research activities carried out by collecting and tracing data and processing (books, literature and library materials) related to the topic of discussion. The type of research is qualitative research which is a particular tradition in social science that is fundamentally dependent on humans in its own region and relates to these people in its discussion and in its terminology. Material of the Law of the Qur'an, hadith, and the opinion of the school of Iman Syafii, Hanafi Faith, Maliki Imam, Hambali Faith. The data analysis method used in this research is analytical descriptive method.

The results of the study explain that dowry may be in the form of money, jewelry, household furniture, animals, services, commercial property or other objects that have a price. or a sack of wheat. If it is not known from various aspects that allow determination of the amount of dowry, then according to all schools except Maliki, the contract remains valid, but the dowry is null. While Maliki believes that the contract is invalid and in fact before mixing at the campuri, the contract is declared valid by using mahar mitsli. Maliki said that if the contract had not been mixed it was invalid. But if there had been a mixture then the contract was declared valid and the wife had the right to mitsli mahr. Meanwhile, Syafi'i, Hanafi and Hambali argue that, the contract remains valid, and the wife has the right to mitsli mahr.
\end{abstract}

Keywords: Comparison, Mazhab, Islamic Marriage. 


\section{PENDAHULUAN}

Salah satu dari usaha Islam ialah memperhatikan dan menghargai kedudukan wanita, yaitu memberinya dan menghargai kedudukan wanita, yaitu memberinya hak untuk memegang urusannya. Di zaman Jahiliyah hak perempuan itu dihilangkan dan disia-siakan, sehingga walinya dengan semena-mena dapat menggunakan hartanya, dan tidak memberikan kesempatan untuk mengurus hartanya, dan menggunakannya.Lalu Islam datang menghilangkan belenggu ini, kepadanya diberi mahar (Sabiq. 2010: 53). Kata lain dari mahar pada zaman sekarang ini adalah maskawin.

Maskawin dalam pembahasan fikih munakahat memiliki beberapa sebutan. Bahkan As San'ani dalam kitab Subulussalam menyatakan bahwa terdapat delapan sebutan untuk maskawin yaitu shidaq, mahar, nahlah, faridhah, hiba', ajr, 'uqr, dan 'alaiq.Kesemua istilah diatas jika diartikan ke dalam Bahasa Indonesia dapat diartikan maskawin. Sedangkan secara istilahi, para ulama memberikan beberapa pengertian.

Ulama telah bersepakat bahwa mahar hukumnya wajib.Mereka mencapai kesepakatan tersebut karena banyaknya nash-nash baik Al-Quran maupun Sunnah Rasulullah yang memerintahkan mahar. Misalnya firman Allah pada surah An-Nisa ayat 24-25 serta hadis di atas. Selain itu, kedudukannya sebagai syarat nikah, bahkan rukun nikah menurut Imam Malik menyebabkan pemberian mahar menjadi sesuatu yang diwajibkan.

Mahar sebaiknya tidak terlalu memberatkan calon suami agar terjadi kesepakatan dalam pelaksanaan dalam memahami ajaran islam terutama dalam hal yang berhubungan dengan kemaslahatan dalam sebuah pernikahan. Mahar haruslah sesuai dengan kadar kemampuan suami, jika memang suaminya seorang yang mampu, maka tidak ada salahnya memberikan mahar yang tinggi untuk menyenangkan hati istrinya. Namun jika ia seorang yang kurang mampu maka pihak istri harus ridha dengan mahar yang disanggupi pihak suami. Permasalahan yang terjadi sekarang orang tidak lagi berpandangan pada hukum islam, disebabkan karena adanya desakan dari tradisi yang membuat seorang wali yang akan menikahkan anak harus melakukan resepsi 
besar-besar sehingga yang terbebani adalah dari pihak yang akan menikahi anak si wali tersebut. Secara hukum ini hal ini sangat memberatkan dan tidak lagi sesuai dengan hukum akad pernikahan itu sendiri terutama saat akan terjadi lamaran dari pihak laki-laki kepada pihak perempuan. Hal ini disebabkan kurang pemahaman dari pihak perempuan dalam melaksanakan akad nikah yang disesuikan dengan hukum islam. Sebenarnya jika ditinjau dari hukum perjanjian akad nikah, berarti adanya pemaksaan dari hukum nikah itu sendiri, karena seakan-akan mahar tersebut adalah sejenis material yang harus dan wajib dikeluarkan dalam jumlah yang banyak. Padahal sesuai dengan aturan islam mahar tersebut diberikan secara keikhlasan dan kerelaan sebagai suatu akad atau perjanjian berdasarkan dari kedua belah pihak yang menyetujui adanya pernikahan.

Berdasarkan permasalahan diatas perlu ditinjau kembali tentang hukum mahar secara Islami yang selama disalahgunakan pemahamannya.Karena kebanyakan orang berpandangan bahwa mahar itu harus mencukupi dari resepsinya juga atau dengan kata ada undangan yang mendatanginya atau menyebarkan kabar gembira kepada orang.Namun terkadang memaksakan hukum yang sebenarnya kepada hukum qias atau mengadakan hukum yang seakan-akan dianggap benar di masyarakat.Karena pandangan dari masyarakat jika tidak membuat atau mengadakan resepsi pernikahan yang besar belum dianggap sebuah keluarga atau belum dianggap sah hukum nikahnya.

Padahal dalam Islam sudah bertentangan karena dalam Al-Quran disebutkan bahwa sesuatu yang membuang-buang.Arti Al-Israa' ayat 26-27 :"Dan janganlah kamu menghambur-hamburkan (hartamu) secara boros. Sesungguhnya pemboros-pemboros itu adalah saudara-saudara setan". Hubungan hukum mahar dengan ayat tersebut sangat berkaitan ketika seorang calon suami dipaksakan untuk mengadakan resepsi pernikahan sementara pihak calon suami tidak mempunyai kecukupan dan diam memaksakannya. Maka secara hukum islam tersebut dianggap haram resepsi yang dilaksanakan dan kebanyakan orang islam sekarang lebih memilih untuk mengadakan resepsi tanpa memperhatikan nilai dari mahar yang diberikan dan nilai dari penikahan yang dilakukan. 
Berdasarkan latar diatas maka perlu diteliti tentang "ANALISIS PERBANDINGAN 4 MAZHAB TENTANG MAHAR PERNIKAHAN DALAM ISLAM"

Tujuan penelitian ini adalah untuk menganalisis: 1) Pandangan Islam tentang Mahar pernikahan. 2) Perbandingan 4 Mazhab Tentang Mahar Pernikahan dalam Islam.

\section{METODE PENELITIAN}

Penulis menggunakan penelitian kepustakaan (library research), yaitu kegiatan penelitian yang dilakukan dengan pengumpulan dan penelusuran data-data serta pengolahan (buku-buku, literatur dan bahan pustaka) yang berkaitan dengan topik pembahasan (Mestika Zed. 2004: 3). Adapun jenis penelitiannya adalah penelitian kualitatif yaitu tradisi tertentu dalam ilmu pengetahuan sosial yang secara fundamental bergantung pada manusia dalam kawasannya sendiri dan berhubungan dengan orang-orang tersebut dalam bahasannya dan dalam peristilahannya. Penelitian ini dilakukan secara normatif yaitu mengkaji secara menyeluruh tentang permasalahan Hukum Islam Tentang Mahar Pernikahan Dari 4 Mazhab tersebut. Penelitian ini berupa penelitian kepustakaan (library research) berkaitan dengan pokok permasalahan, membaca dan meneliti data-data yang didapat untuk memperoleh data yang lengkap sekaligus terjamin dan mencatat data secara sistematis dan konsisten.

Pada penelitian hukum normatif yang hanya mengenal data sekunder saja, jenis data pada penelitian ini adalah bahan hukum primer, bahan hukum sekunder, dan bahan hukum tersier. Bahan Hukum Primer yaitu bahan-bahan hukum yang mengikat, seperti al-Qur'an, hadis, dan pendapat mazhab Iman Syafii, Iman Hanafi, Imam Maliki, Iman Hambali. Bahan Hukum Sekunder ialah bahan hukum yang memberikan penjelasan mengenai bahan hukum primer, atau bahan pustaka yang mengacu atau mengutip bahan hukum primer.

Metode analisis data yang digunakan dalam penelitian ini adalah metode deskriptif analitis, di mana permasalahan akan dipaparkan secara detail, kemudian diadakan analisis isi dan analisis kritis.Analisis Deskriptif yaitu analisis ini bertujuan 
untuk memberikan deskripsi mengenai subyek penelitian dari perbedaan mazhab dan bab III yang menguraikan tentang biografi, pendapat, dan metode istinbath hukum mazhab Iman Syafii, Iman Hanafi, Imam Maliki, Iman Hambali. Analisis Kritis yaitu untuk mengadakan rincian tentang obyek yang diteliti.

\section{HASIL PENELITIAN}

Penelitian ini berhubungan dengan Analisis Perbandingan 4 Mazhab Tentang Mahar Pernikahan Dalam Islam. Maka berbedasarkan dari penelitian

\section{Pandangan Islam Tentang Mahar Pernikahan}

Mahar merupakan pemberian dari mempelai pria kepada seorang wanita yang dinikahinya, yang nantinya mahar tersebut akan menjadi hak milik istrinya secara penuh. Dalam praktiknya, sebenarnya tidak ada sebuah batasan khusus tentang besaran mahar dalam pernikahan Islam. Mahar juga bisa sesuatu yang bersifat akhirati seperti keimanan, seperti yang telah diceritakan dalam sejarah, mahar seperti yang pernah di minta Ummu Salamah dari Abu Thalhah, dapat juga berupa ilmu ataupun hafalan Al-Quran, atau bisa juga berupa kemerdekaan/pembebasan dari perbudakan, dan bisa dengan apa saja yang bisa diambil upahnya/manfaatnya, seperti yang dijelaskan dalam QS. Al-Qoshosh ayat 27.

Dalam kisah lainnya Rasulullah SAW pernah menikahkan putrinya yang bernama Fatimah dengan Sayyidina Ali ra menggunakan mahar baju besi milik Sayyidina Ali.Diriwayatkan oleh Ibnu Abbas, "Setelah Ali menikah dengan Fatimah, Rasulullah SAW mengatakan kepadanya, "Berikanlah sesuatu padanya (Fathimah)." Ali menjawab: Aku tidak punya sesuatu pun.' Maka beliau saw bersabda, 'Dimana baju besimu? Berikan baju besimu itu padanya.'Maka Ali kemudian memberikan baju besinya pada Fatimah.(HR Abu Dawud $\mathcal{E}$ Nasa'i).

Bahkan pada seorang laki-laki tidak memiliki sesuatu berupa harta yang dapat diberikan sebagai mas kawin atau mahar, Rasulullah SAW tidak pernah menolak untuk menikahkannya dengan menggunakan mahar beberapa surat yang ada di dalam Al-Qur'an yang telah dihafalnya. Dikisahkan ada seorang pria yang meminta untuk dinikahkan oleh Rasulullah saw, namun dia tidak memiliki apapun sebagai 
mahar, walaupun hanya sebuah cincin dari besi. Lalu Rasulullah bertanya padanya, 'Apakah Kamu menghafal Al-Qur'an?'Ia menjawab, 'Ya, aku hafal surat ini \& surat itu (dia menyebutkan beberapa surat di dalam Al-Qur'an). 'Maka beliau saw bersabda, 'Aku menikahkan Kamu dengannya dengan mahar berupa surat Al-Quran yang Kamu hafal itu'. (disarikan dari hadits yang cukup panjang di dalam Kitab Shahih Bukhari no: 1587).

Dari beberapa hadist dan ayat al-quran diatas, dapat Kita simpulkan bahwa memang tidak ada batasan mengenai bentuk serta besarnya mahar pernikahan dalam Islam, namun yang disunnahkan ialah mahar tersebut disesuaikan dengan kemampuan dari calon suami. Sebagai calon suami tentu saja ingin memberikan mas kawin yang terbaik untuk istrinya, tapi seringkali calon suami memberikan mahar berupa sesuatu yang dibutuhkan oleh istri, atau setidaknya bukan merupakan sesuatu yang dia inginkan.

Sebagaimana Rasulullah SAW pernah mengatakan:"Sebaik-baik wanita ialah yang paling murah maharnya." (HR. Ahmad, ibnu Hibban, Hakim \& Baihaqi)

Demikian pembahasan tentang mahar yang dapat kami samapaikan, Semoga bahasan singkat tentang mahar pernikahan diatas bisa membantu Anda untuk memahami hakikat mas kawin yang sebenarnya. Jikamampu memberikan mas kawin yang mahal dan banyak tanpa menyusahkan, silahkan karena itu tidak dilarang. Namun, apabila tidak mampu, sebaiknya jangan memaksakan. Demikian juga calon istri, sebaiknya jangan menuntut mahar yang sekiranya akan menyusahkan calon suaminya. Selamat menikah dan meraih keberkahan serta memperoleh keturunan yang baik juga shalih/shalihah.

Wahbah Zuhaili menjelaskan bahwa ada 2 jenis mahar, yaitu mahar musamma dan mahar mitsil, yang penjelasannya adalah sebagai berikut:

1. Mahar musamma adalah mahar yang dinyatakan secara jelas dalam akad yang menyerahkannya bisa dilakukan ketika akad dilangsungkan dan bisa pula setelah akad, selama didasarkan pada kesepakatan calon suami dan istri

2. Mahar mitsil adalah sejumlah mahar yang sama nilainya dengan mahar yang diterima oleh wanita menikah dalam pihak ayah, (seperti adik kakak perempuan 
dan keponakan perempuan ayah). Oleh karena setiap daerah mempunyai ketentuan mahar yang berbeda, maka ukuran yang diambil adalah kebiasaan yang berlaku dalam perkawinan.

Mahar musamma wajib diberikan suami sesuai dengan jumlah yang disepakati dalam akad. Mengenai mahar mitsil, ulama menyatakan bahwa kewajiban membayar mahar tersebut muncul dalam keadaan-keadaan sebagai berikut:

1. Apabila dalam akad nikah tidak disebutkan jenis dan jumlah mahar oleh suami.

2. Apabila suami istri sudah ada kesepakatan untuk tidak memakai mahar dalam perkawinan mereka. Menurut ulama juga diwajibkan mahar mitsil karena kesepakatan tersebut tidak dibenarkan meskipun mahar tersebut adalah hak istri.

3. Benda yang dijadikan mahar ketika berlangsung akad nikah tidak bernilai harta dalam Islam, seperti minuman khamar dan babi.

4. Apabila nikah tersebut adalah nikah fasid.

Kadar Mahar dalam Islam tidak Menetapkan berapa banyak mahar yang harus diberikan kepada calon istri.hal ini disebabkan adanya perbedaan antara sesama manusia. Ada orang yang kaya, adapula yang miskin, ada yang lapang dan ada pula yang disempitkan rezekinya. Di samping itu, setiap masyarakat mempunyai adat dan kebiasaan yang berbeda.Oleh karena itu, masalah mahar diserahkan berdasarkan kemampuan masing-masing orang sesuai dengan adat dan tradisi yang berlaku di masyarakat. Bahkan, Islam membolehkan memberi mahar dengan apa saja, asalkan bermanfaat. misalnya cicin besi segantang kurma, atau mengajarkan Al-Quran. dan sebagainya atas kesepakatan kedua belah pihak.

Rusaknya mahar karena bisa terjadi karena barang itu sendiri atau karena sifatsifat barang itu sendiri, seperti tidak diketahui atau sulit diserahkan. Mahar yang rusak karena zatnya sendiri, yaitu seperti khamar, babi dan barang-barang yang tidak boleh dimiliki, sedangkan mahar yang rusak karena sulit dimiliki atau diketahui, pada dasarnya disesuaikan dengan jual beli yang mengandung lima persoalan pokok, yaitu:

1. Barangnya tidak boleh dimiliki.

2. Mahar digabungkan dengan jual beli.

3. Penggabungan mahar dengan pemberian. 
4. Cacat pada mahar.

5. Persyaratan dalam mahar.

Dalam hal barangnya tidak boleh dimiliki seperti: khamar, babi, dan buah yang belum masak atau unta yang lepas, maka Imam Hanifah berpendapat bahwa akad nikahnya tetap sah apabila telah memenuhi mahar misil. Akan tetapi, Imam Malik berpendapat tentang dua riwayat yang berkenaan dengan persoalan ini. Pertama, mengatakan bahwa akad nikahnya rusak dan harus dibatalkan (fasakh), baik sebelum maupun sesudah dukhul. Pendapat ini juga dikemukakan oleh Abu Ubaid. Kedua, mengatakan apabila telah dukhul, maka akad nikah menjadi tetap, dan istri memperoleh mahar mitsil.

Jika seorang laki-laki benar-benar tidak mampu untuk memberikan mahar dalam bentuk materi (harta), maka ia bisa memberikan mahar dalam bentuk non materi (bukan harta). Hendaknya sesuatu yang non materi tersebut memiliki manfaat yang kembali kepada si wanita. Mahar tidak mesti berupa uang atau harta benda, akan tetapi boleh juga hal-hal lainnya. Untuk lebih jelasnya, berikut ini hal-hal yang dapat dijadikan maskawin atau mahar. Jadi dalam hukum Islam mahar yang diberikan oleh mempelai laki-laki kepada mempelai perempuan bukan diartikan sebagai pembayaran, seolah-olah perempuan yang hendak dinikahi telah dibeli seperti barang.Pemberian mahar dalam syariat Islam dimaksudkan untuk mengangkat harkat martabat kaum perempuan yang sejak zaman jahiliah telah diinjak-injak harga dirinya, status perempuan tidak dianggap sebagai barang yang diperjualbelikan sehingga perempuan tidak berhak memegang harta bendanya sendiri atau walinya dengan semena-mena boleh menghabiskan hak-hak kekayaannya.

\section{Perbandingan 4 Mazhab Tentang Mahar Pernikahan dalam Islam}

Begitu juga mahar dapat gugur apabila istri yang belum digauli melepaskan maharnya atau rnenghibahkan padanya.Dalarn hal seperti ini, gugurnya mahar karena perempuan sendiri yang menggugurkannya.Sedang mahar sepenuhnya berada dalam kekuasaan perempuan. 


\section{Pendapat Imam Syafi'i}

Tentang Mahar Berupa Jasa Imam Syafi'i memberikan definisi yang terbuka dan jelas tentang mahar, yakni ,sesuatu (bisa harta maupun jasa) yang wajib diberikan oleh suami kepada istri untuk menghalalkan seluruh anggota badannya'. Prinsip bagi Imam Syafi'i yaitu asal sesuatu yang dijadikan mahar itu bernilai dan berharga, maka boleh digunakan sebagai maskawin, maka jelas bahwa mahar berupa jasa atau manfaat (non materi) diperbolehkan. Suatu barang tidak boleh dijadikan maskawin, kecuali diketahui adanya, dan benda itu halal dijual baik dengan tunai atau dengan ditangguhkan. Maskawin yang diberikan bisa sedikit dan bisa juga banyak itu sama saja, dengan demikian boleh orang itu mengawini seorang wanita dengan maskawin hanya sedirham atau kurang dari sedirham.

Imam Syafi'i membolehkan adanya mahar dengan menjahit pakaian, membangun rumah, melayani sebulan, atau mengajarkan al-Qur'an kepada istri, yang merupakan mahar jasa. Menurut Imam Syafi'i, setiap manfaat yang dimiliki dan halal harganya serta mempunyai nilai kesederhanaan pada mahar itu lebih beliau sukai. Beliau memandang sunnah, bahwa tidak berlebih pada mahar. Imam Syafi'i, dalam melakukan pembahasan mengenai mahar jasa di atas, mengungkapkan beberapa dalil yang tercantum dalam kitabnya Ahkamul Qur'an yaitu firman Allah SWT QS. an-Nisa' ayat 24. Ayat di atas menjelaskan bahwa wajib atas orang yang menikah lagi mencampuri, memberikan maskawin. Imam Syafi'i membolehkan penangguhan keseluruhan atau sebagian mahar sampai jangka waktu yang diketahui karena mahar adalah pengganti dalam akad saling memberi ganti, jika di mutlakkan penentuannya pasti ada jalan keluar. Jika ia di tangguhkan sampai jangka waktu yang tidak diketahui hukumya tidak sah karena merupakan sesuatu yang tidak diketahui. Jika ditangguhkan tanpa menyebutkan waktunya menurut Imam Syafi'i mahar fasid dan ia tidak berhak mendapatkan mahar mithil. Jika suami tidak dapat membayar mahar dengan cepat maka menurut Imam Syafi'i si istri memiliki hak untuk meminta pembatalan nikah ketika itu, ia memiliki hak untuk membatalkan perkawinannya sebelum dan sesudah persetubuhan. 
Maka dapat dijelaskan bahwa Menurut Imam Syafi'i mahar tidak mengenal batas tinggi dan rendahnya. Segala sesuatu yang dapat menjadikan berharga bagi yang lain dapat dijadikan mahar. Pemberian mahar dalam ukuran sedang lebih disukai. Lebih baik jika seseorang tidak memberikan mahar kepada istrinya melebihi mahar Rasulullah Saw kepada istri-istrinya, dan yang dibayarkan untuk putri-putri beliau yaitu lima ratus dirham sebagai upaya mencari berkah dengan cara meneladani setiap perkara yang dikerjakan Rasulullah Saw.

Kitab al-Umm karya Imam Syafi'i menjelaskan masalah maskawin sebagai berikut: setiap barang yang bisa dijual atau disewakan dengan suatu harga, maka barang tersebut bisa dijadikan maskawin. Sebaliknya bila barang itu tidak mempunyai harga dan tidak bisa dijual, maka barang tersebut tidak layak menjadi maskawin.Suatu barang tidak boleh dijadikan maskawin, kecuali diketahui adanya, dan benda itu halal dijual baik dengan tunai atau dengan ditangguhkan. Pendapat Imam Syafi'i tentang kebolehan perempuan mengawini laki-laki dengan mahar lelaki itu menjahit kepadanya pakaian atau membangun baginya rumah atau melayaninya sebulan atau baginya lelaki itu berbuat suatu perbuatan apa saja atau ia mengajarkan Alquran. Ulama Syafi'iyah mengatakan mahar tidak ada batasan minimal dalam mahar, baik sedikit atau banyak karena Allah tidak menyebutkan larangan terhadap qintar yang berarti harta yang banyak serta tidak batasan minimal. Hal itu ditunjukkan oleh sunnah Nabi dan Qiyas terhadap Ijma' dalam masalah ini. Jadi, batasan minimal boleh dibayarkan sebagai mahar sama dengan batasan minimal sesuatu yang dijadikan manusia sebagai harta benda. Apayang dianggap dirusak oleh seseorang milik orang lain itu memiliki nilai dan apa yang biasa diperjualbelikan diantara manusia. Dapat dipahami dengan jelas dalam Alquran bahwa laki-laki yang menikahi dan telah menggauli itu wajib membayar mahar sesuai dengan kesepakatan. Allah Swt juga menetapkan ketentuan mahar bagi hamba sahaya yang akan menikah dengan seizin tuannya. 


\section{Pendapat Imam Abu Hanifah}

Tentang Mahar Berupa Jasa Abu Hanifah dari madzhab Hanafi, berpendapat bahwa mahar adalah kewajiban tambahan dalam akad nikah, sama statusnya dengan nafkah. Mahar mengajarkan al-Qur'an atau melayani istri menurut Imam Kamaluddin bin al-Humam al-Hanafi dalam kitab Syarh Fathul Qadir yaitu: Artinya: “Jika seseorang yang merdeka menikah dengan mahar akan melayani istri 1 tahun atau mengajarinya al-Qur'an, maka bagi istri adalah mahar mitsil. Muhammad berkata: bagi istri tersebut adalah harga pelayanan. Jika seorang hamba sahaya menikah dengan izin tuannya dengan mahar melayani istri selama 1 tahun, maka diperbolehkan dan bagi istri mendapat pelayanan suami tersebut".

Penjelasan dari kitab di atas adalah jika seseorang yang merdeka,menikah dengan mahar akan melayani istri selama satu tahun atau mengajarinya al-Qur'an, maka bagi istri adalah mahar mitsil. Pendapat hukum mengajarkan al-Qur'an sebagai mahar menurut Imam Kamaluddin bin al-Humam al-Hanafi dengan mengutip Imam Abu Hanifah yaitu bahwa mengajarkan al-Qur'an sebagai mahar adalah fasad (rusak) dan harus mengganti mahar mitsil. Dasar Imam Kamaluddin bin al-Humam al-Hanafi dalam mengajarkan al-Qur'an sebagai mahar diganti dengan mahar mitsil adalah dalam firman Allah QS. an-Nisa' ayat 24:

Artinya: “Dan (diharamkan juga kamu mengawini) wanita yang bersuami, kecuali budak-budak yang kamu miliki (Allah telah menetapkan hukum itu) sebagai ketetapan-Nya atas kamu. dan Dihalalkan bagi kamu selain yang demikian (yaitu) mencari istri-istri dengan hartamu untuk dikawini bukan untuk berzina. Maka istriistri yang telah kamu nikmati (campuri) di antara mereka, berikanlah kepada mereka maharnya (dengan sempurna), sebagai suatu kewajiban; dan Tiadalah mengapa bagi kamu terhadap sesuatu yang kamu telah saling merelakannya, sesudah menentukan mahar itu. Sesungguhnya Allah Maha mengetahui lagi Maha Bijaksana".

Madzab Hanafi mengatakan jika laki-laki menikah dengan mahar manfaat benda berupa menghuni rumah miliknya (laki-laki), menaiki hewannya, mengangkut barang bawaan di atas untanya, menanam di lahannya selama kurun waktu tertentu, maka penyebutan mahar sah dan perempuan berhak mendapatkan manfaat yang telah 
disebutkan. Hal ini tidak ada perselisihan, ukuran minimal mahar mitsil (sepadan) menurut Abu Hanifah adalah sepuluh dirham, jika lelaki menikah dengan mahar berupa benda yang dapat diukur, ditimbang, atau dihitung sedangkan harganya pada waktu akad setara dengan 10 dirham atau lebih, kemudian harganya berkurang di bawah 10 dirham sebelum diserahkan, maka perempuan tidak memiliki hak untuk menuntut lebih, karena yang dianggap adalah harga di saat akad. Adapun jika lelaki menikah dengan mahar benda yang harganya setara 8 dirham di saat akad, maka perempuan menuntutlah dua sisanya, meski harganya di saat penyerahan naik menjadi 10 dirham.

Tiga imam Hanafiyah (Abu Hanifah, Abu Yusuf, Muhammad bin Hasan alSyaibani) berpendapat bahwa al-Qur'an dan hukum-hukum agama tidak boleh dijadikan pengajaran sebagai imbangan harta sehingga tidak sah untuk dijadikan mahar, namun darinya wajib dibayar mahar mitsil, karena ia merupakan manfaat yang tidak bisa mengimbangi harta (tidak bisa dihitung dengan uang). Terkadang memberi fatwa tentang diperbolehkannya mengambil gaji atas pengajaran al-Qur'an dan ilmuilmu agama karena darurat, karena terkadang tidak ditemukan orang yang mengajarkan ilmu-ilmu agama padahal hal itu wajib atas kaum muslimin.Kaidahnya adalah sesuatu yang patut mendapatkan upah sah dijadikan mahar, karena upah merupakan harta yang memiliki harga yang bisa menjadi mahar.

Berdasarkan hal ini, boleh memfatwakan keabsahan menjadikan pengajaran alQur'an dan fiqh sebagai mahar secara pasti. Sebagian ulama menentang pendapat itu dari sisi yang lain, yakni dengan melihat bahwa dengan demikian laki-laki akan menjadi pembantu perempuan, sedangkan pembantu lelaki merdeka terhadap perempuan diharamkan maka tidak bisa menjadi mahar. Penentangan ini tidak ada arti apa-apa, karena seorang pengajar al-Qur'an dan ilmu tidak bisa disebut sebagai pembantu, bahkan secara urfi ia disebut sebagai tuan.

Mahar dengan mendatangkan laki-laki lain yang tidak ada kekhawatiran terjadinya fitnah, maka boleh-boleh saja, sedangkan jika lakilaki lain itu tidak rela menjadi pelayan maka mahar ditetapkan harga pelayanannya. Seorang laki-laki menikah dengan mahar mendatangkan lakilaki lain sebagai pelayan selama waktu 
yang tidak ditentukan, dalam masalah ini juga terdapat perincian yang telah disebutkan yakni boleh jika tidak ada fitnah dan tidak boleh jika ada fitnah.

\section{Pendapat Iman Maliki}

Imam Maliki mendefinisikan mahar sebagai sesuatu yang diberikan kepada seorang istri sebagai imbalan persetubuhan dengannya.Imam Syafi'i mendefinisikan sebagai sesuatu yang diwajibkan sebab pernikahan atau persetubuhan, atau lewatnya kehormatan perempuan dengan tanpa daya seperti akibat susuan dan mundurnya para saksi. Penelitian Mohammad 'Ainul Fikri Kholili yang berjudul " Studi Analisis Tentang Penundaan Pembayaran Mahar Perspektif Imam Malik". Imam Malik berpendapat jika penundaan pembayaran mahar diperbolehkan dengan syarat menyebutkan tenggang waktu pembayaran mahar tersebut.Imam Malik juga memberikan batasan waktu penundaan pembayaran mahar dan juga menganjurkan pembayaran dengan sebagian mahar dimuka jika hendak menggauli istrinya.Imam Malik mendasarkan pendapatnya tersebut pada praktik amal perbuatan yang dilakukan oleh penduduk madinah saat itu.

Sementara bagai jumhur ulama Malikiyah menyatakan mahar adalah rukun memandang dari sisi sah dan tidak sahnya akad nikah bergantung dari eksitensi mahar yang termasuk elemen pokok dalam nikah, sehingga posisi mahar sama dengan al mahal (suami dan istri), al wali, dan al shigot (ijab dan kabul). Pendapat Imam maliki yang mengatakan mahar sebagai rukun nikah secara tidak langsung memiliki implikasi yang sangat penting dan memposisikan perempuan pada posisi yang tinggi, demikian bisa dilihat dari implikasi yang dihasilakan. Mahar (al shodaq) dalam akad nikah merupakan rukun dipandang dari sisi tidak sahnya pensyaratan yang bersifat menggugurkan atau mentiadakan (al isqot) status mahar.Konsekuensi pandangan ini adalah status tidak sahnya akad nikah, apabila disyaratkan dalam akad tersebut pentiadaan mahar. Dalam hal ini menjadi tidak ada kompromi untuk menggugurkan mahar yang akan diberikan kepada pihak perempuan.

Meskipun ada kesepakan dari kedua belah pihak untuk menghapuskan mahar.Secara tidak langsung, implikasi hukum ini memberikan pesan penghargaan 
kepada perempuan (dalam bentuk mahar) tidak bisa ditolerir, bahkan nabi sendiri dalam satu kesempatan, ketika menyarankan kepada sahabatnya untuk menikahi seorang perempuan harus memberikan mahar, meski dari cincin besi atau bacaan alQuran (untuk mengajarkan kepada pihak perempuan).

Menurut analisis penulis, tampaknya pendapat Imam Malik ini untuk mengangkat harkat dan martabat wanita agar wanita tidak direndahkan, karena kalau mahar dijadikan sebagai syarat, bukan rukun maka akan banyak celah untuk melakukan penghapusan (isqat) terhadap pembayaran mahar, maka seakan-akan wanita sebagai makhluk yang tidak punya harga. Dari sini terlihat bahwa pemikiran Malik menunjukkan keberpihakannya pada kaum wanita.

Pendapat ulama Maliki tentang mahar sebagai rukun nikah dibangun atas dasar adanya keserupaan antar akad nikah dan akad jual beli dari sisi pondasi rukun-rukun yang mendasari legal (sah) atau ilegalnya (tidak sah) akad tersebut.sehingga ada upaya melakukan Qiyas dalam menentukan mahar sebagai rukun nikah. Langkahnya adalah dengan mempersamakan suatu kasus yang tidak ada nash hukumnya dengan suatu kasus yang ada nash hukumnya, dalam hukum yang ada nashnya, karena persamaan yang kedua itu dalam illat (sesuatu yang menjadi tanda) hukumnya.

Istinbat hukum Imam Malik yang menggunakan qiyas sebagai dasar dalam menetapkan pendapatnya, karena qiyas merupakan sumber hukum Islam yang kelima bagi Imam Malik dan disepakati oleh ulama. Seluruh umat Islam, baik yang ahli naql maupun ahli aql telah sepakat bahwa qiyas merupakan dasar hukum Islam, yaitu salah satu sumber hukum Islam dan juga sepakat tentang diwajibkannya mengikuti alQur'an.Ulama mazhab secara umum sepakat menjadikan qiyas sebagai hujjat syariyat dan membenarkan pengambilan prodak hukum dengan menggunakan qiyas.Adapun dasar hukumnya adalah bahwa Allah SWT menyarankan kepada manusia apabila berselisih dalam satu perkara maka kembalilah kepada al-Qur'an.

Selain menggunakan qiyas, pendapat Imam Malik yang menyatakan mahar sebagai rukun nikah sebagai bentuk penghargaan terhadap perempuan adalah merupakan langkah istihsan. Sebagai mana diketahui, bahwa malikiyah adalah mazahab yang menggunakan konsep istihsan sebagi langkah penggalian hukum. 
Adapun langkahnya adalah dengan menurut hukum dengan mengambil maslahah yang merupakan bagian dalam dalil yang bersifat kully (menyeluruh) dengan maksud mengutamakan al-istidlal al-Mursal dari pada qiyas, sebab menggunakan istihsan itu, tidak berarti hanya mendasarkan pada pertimbangan perasaan semata melainkan mendasarkan pertimbangannya pada maksud pembuat syara' secara keseluruhan. Melihat dari metode yang digunakan oleh Imam Malik dalam melakukan instinbath hukum, yaitu dengan mengambil langkah qiyas dan istihsan, maka prodak hukum yang dihasilkan, yaitu menganggap mahar sebagai rukun nikah adalah bisa dijadikan sebagai dalil syar'i, dan diperbolehkan menggunakan dan ikut dalam pendapat ini.

\section{Pendapat Imam Hambali}

Imam Hambali mendefinisikan mahar sebagai pengganti dalam akad pernikahan, baik mahar ditentukan di dalam akad atau ditetapkan setelahnya dengan keridaan kedua belah pihak atau hakim atau pengganti dalam kondisi pernikahan seperti persetubuhan yang memiliki syubhat dan persetubuhan secara paksa.Hambaliberpendapat bahwa tidak ada batas minimal dalam mahar.Hambali mengatakan bahwa manakala salah satu di antara mereka meninggal dunia sebelum terjadi percampuran, maka di tetapkan bahwa si istri berhak atas mahar mitsli secara penuh sebagaimana ketentuan yang berlaku bila suami telah mencapuri istrinya. Hambali berpendapat bahwa barang siapa yang memperkosa seorang wanita, maka dia harus membayar mahar mitsli, tetapi bila wanita itu bersedia melakukannya (denag rela), maka laki-laki itu tidak harus membayar mahar apapun.

Imam Ahmad Hambali membolehkan mahar dengan ayat al-Quran atau jasa bila memang ia tidak mampu memberikan yang lain, agar tidak ada persetubuhan antara laki-laki dan perempuan sebelum memberikan sesuatu sebagai maharnya. Pasangan yang hendak menikah disunnahkan untuk menjalankan akad nikah kecuali setelah adanya maskawin, supaya dapat meredam pertengkaran dan lebih bermanfaat bagi seorang istri dan bila memang terjadi talaq sebelum bersetubuh, maka bagi seorang suami wajib membayar mahar yang telah disebutkan. Tetapi bila tidak menyebutkan mahar ketika melakukan akad nikah, maka bagi sang istri tidak wajib 
mendapatkan mahar tersebut, namun yang wajib baginya adalah mut'ah (pemberian). Dalam kitab Musnad Ahmad bin Hanbal, menerangkan tentang mengajarkan satu surat dari al-Qur'an setelah menikah, yaitu:“Dari Sahl bin Sa'ud asSa'idi bahwa Rasulullah SAW bersabda kepada sesorang pergilah, karena aku telah menikahkan kamu dengan dia, kemudian lelaki itu mengajarkan istrinya satu surat dari al-Qur'an"

Seorang merdeka sah menikah dengan seorang wanita dengan mahar melayaninya selama waktu tertentu, atau dengan mahar mendatangkan pelayan merdeka untuk melayani mempelai wanita selama waktu tertentu, lebih-lebih jika yang didatangkan adalah pelayan hamba sahaya. Sah menikah dengan mahar perbuatan yang diketahui seperti menjahit pakaian tertentu, baik ia sendiri yang menjahit atau orang lain, jika pakaian tersebut rusak sebelum dijahit maka mempelai lelaki wajib membayar setengah harga upahnya, meskipun ia mengeluarkan talak sebelum berhubungan suami istri.

Menikah sah dengan mahar mengajarkan bab-bab fiqh atau hadits, atau mengajarkan sesuatu yang diperbolehkan dari sastra, syair, atau mengajarkan keterampilan, kepenulisan, dan pekerjaan lainnya yang boleh dimintakan upah, jika pengajaran tersebut tidak mungkin dilakukan (karena suatu alasan) maka mempelai lelaki wajib menyerahkan upah orang yang bisa mengajarkannya.

Mempelai lelaki berkewajiban memberikan upah pengajarannya, apabila ia belum mengajarkan dan mengeluarkan talak sebelum melakukan hubungan suami istri, serta jika talak terjadi setelah mengajarkan maka ia bisa meminta kembali setengahnya dalam bentuk upah jika perpisahan terjadi dari pihak mempelai lelaki, jika perpisahan terjadi dari pihak mempelai perempuan, maka mempelai lelaki bisa meminta kembali seluruh upahnya.

Ulama Hanabilah berpendapat mahar adalah suatu imbalan dalam nikah baik yang disebutkan di dalam akad atau yang diwajibkan sesudahnya dengan kerelaan kedua belah pihak atau hakim, atau imbalan dalam hal-hal yang menyerupai nikah seperti watha' syubhat dan watha' yang dipaksakan. Ulama Hanabilah juga mengatakan sah mahar berupa manfaat seperti halnya mahar berupa benda. Seseorang 
menikah dengan seorang wanita dengan mahar menggembalakan kambingnya atau membajak tanahnya dan sebagainya maka mahar sah dengan syarat manfaat harus diketahui (ma'lumah), apabila tidak diketahui (majhulah) maka penyebutan mahar tidak sah dan diwajibkan mahar mitsil.

\section{Perbedaan keempat Imam}

Imam Syafi'i berpendapat bahwa mahar tidak mengenal batas tinggi dan besarnya mahar. Segala sesuatu yang dapat menjadikan berharga bagi sesuatu yang lain dapat dijadikan mahar. Begitu pula dengan Syariat Islam juga tidak menetapkan jumlah besar atau kecil mahar, karena adanya perbedaan kaya dan miskin, lapang dan sempit rezekinya.Selain itu hampir masyarakat mempunyai adat dan tradisinya sendiri.Karena itu Islam tidak menyerahkan mahar oleh sejumlah mahar itu berdasarkan kemampuan masing-masing orang atau tradisi keluarganya. Imam Malik berpendapat bahwa paling sedikit mahar itu harus mencapai seperempat dinar emas atau perak seberat tiga dirham atau barang yang sebanding dengan tiga dirham sedangkan Imam Abu Hanifah berpendapat bahwa mahar paling sedikit adalah sepuluh dirham. Para ulama Malikiyah memandang kepada apa yang dikatakan Imam Malik, mereka pada awalnya melarang menjadikan manfaat sebagai mahar. Mereka memandang kepada apa yang dikatakan bahwa setiap orang yang orang yang memperbolehkan mahar manfaat, maka mereka membiarkan mahar manfaat jika terlanjur terjadi. Ulama Malikiyah mengatakan mahar itu sah berupa benda dari emas, perak, barang dagangan, hewan, rumah, dan sebagainya.

Dari sekian pendapat Imam Imam hanya pendapat dari Imam Syafi'i yang tidak menjadikan mahar sebagai rukun perkawinan, tetapi sebagai syarat sah saja. Sedangkan Imam yang lain seperti Imam Maliki menjadikan kedudukan mahar sebagai rukun dalam perkawinan.

Jadi mahar boleh berupa uang, perhiasan, perabot rumah tangga, binatang, jasa, harta perdagangan atau benda-benda lainnya yang mempunyai harga.Disyaratkan bahwa mahar harus diketahui secara jelas dan detail, misalnya seratus lire, atau secara global semisal sepotong emas atau sekarung gandum.Kalau tidak bisa diketahui dari 
berbagai segi yang memungkinkan diperoleh penetapan jumlah mahar, maka menurut seluruh mazhab kecuali Maliki, akad tetap sah, tetapi maharnya batal.Sedangkan Maliki berpendapat bahwa akadnya tidak sah dan di faskh sebelum terjadi percampuran, tetapi bila telah di campuri, akad dinyatakan sah dengan menggunakan mahar mitsli. Maliki mengatakan bahwa bila belum terjadi percampuran akadnya tidak sah.Tetapi bila telah terjadi percampuran maka akadnya dinyatakan sah dan si istri berhak atas mahar mitsli. Sementara itu, Syafi'i, Hanafi dan Hambali berpendapat bahwa, akad tetap sah, dan si istri berhak atas mahar mitsli.

\section{KESIMPULAN}

Berdasarkan hasil penelitian

1. Pandangan Islam tentang Mahar pernikahan Jadi dalam hukum Islam mahar yang diberikan oleh mempelai laki-laki kepada mempelai perempuan bukan diartikan sebagai pembayaran, seolah-olah perempuan yang hendak dinikahi telah dibeli seperti barang.Pemberian mahar dalam syariat Islam dimaksudkan untuk mengangkat harkat martabat kaum perempuan yang sejak zaman jahiliah telah diinjak-injak harga dirinya, status perempuan tidak dianggap sebagai barang yang diperjualbelikan sehingga perempuan tidak berhak memegang harta bendanya sendiri atau walinya dengan semena-mena boleh menghabiskan hak-hak kekayaannya.

2. Perbandingan 4 Mazhab Tentang Mahar Pernikahan dalam Islam Jadi mahar boleh berupa uang, perhiasan, perabot rumah tangga, binatang, jasa, harta perdagangan atau benda-benda lainnya yang mempunyai harga.Disyaratkan bahwa mahar harus diketahui secara jelas dan detail, misalnya seratus lire, atau secara global semisal sepotong emas atau sekarung gandum.Kalau tidak bisa diketahui dari berbagai segi yang memungkinkan diperoleh penetapan jumlah mahar, maka menurut seluruh mazhab kecuali Maliki, akad tetap sah, tetapi maharnya batal.Sedangkan Maliki berpendapat bahwa akadnya tidak sah dan di faskh sebelum terjadi percampuran, tetapi bila telah di campuri, akad dinyatakan sah dengan 
menggunakan mahar mitsli. Maliki mengatakan bahwa bila belum terjadi percampuran akadnya tidak sah.Tetapi bila telah terjadi percampuran maka akadnya dinyatakan sah dan si istri berhak atas mahar mitsli. Sementara itu, Syafi'i, Hanafi dan Hambali berpendapat bahwa, akad tetap sah, dan si istri berhak atas mahar mitsli.

\section{DAFTAR PUSTAKA}

Abdul Rahman Ghozali. 2008. Figh Munakahat. Jakarta: Prenada Media Group.

Abdulkadir Muhammad. 2000. Hukum Perdata Indonesia. Bandung: PT. Citra Aditya Bakti. hlm. 76

Abdurrahman Al-Jaziri. 1990. al-Fiqh Ala al-Madazhib al-Arba'ah, Juz IV, Beirut: Dar Al- kitab Al-Ilmiyah,

Amir Syarifuddin. 2006. Hukum Perkawinan Islam di Indonesia, (Jakarta : Kencana

Amir Syarifuddin. 2009. Hukum Perkawinan Islam di Indonesia. Jakarta: KencanaNasiri. 2010. Hebohnya Kawin Misyar. Surabaya: Al Nur

Amiruddin \& Zainal Asikin. 2006. Pengantar Metode Penelitian Hukum. Cet. III, Jakarta: Raja Grafindo Persada

Atabik Ali dan Zuhdi muhdlor, Kamus Kontemporer Arab Indonesia, Yogyakarta: Multi Karya Grafika.

Cik Hasan Bisri, 2004. Pilar-pilar Penelitian Hukum Islam dan Pranata Sosial. Cet. I, Jakarta: Raja Grafindo Persada

Hamka, Tafsir al-Azhar, Juz IV, Jakarta: PT Pustaka Panji Mas, 1999, hlm. 294.

Imam Taqiyuddin Abu Bakar Ibn Muhammad Al-Hussaini, Kifayah Al- Akhyar, Beirut: Dar Al-Kutub al-Ilmiah, tth, Juz 2

Lexy J. Moleong. 2001. Metodologi Penelitian Kualitatif, Bandung: PT. Remaja Rosda Karya

M. Ahmad Tihami dan Sohari Sahrani. 2009. Fiqih Munakahat (Kajian Fiqih Nikah Lengkap). Jakarta: Rajawali Press,

Mestika Zed. 2004. Metode Penelitian Kepustakaan, Jakarta: Yayasan Obor Indonesia

S Munir. 2007. Figh Syari'ah. Solo: Amanda 
Saifuddin Azwar. 2005. Metode Penelitian, Yogyakarta: Pustaka Pelajar, Cet. I

Sayyid Sabiq. 2010. Figh Sunnah VII. Bandung: PT Alma'arif.

Slamet Abidin dan Aminuddin. 2010. Fiqh Munakahat 1. Bandung: CV Pustaka Setia.

Soemiyati.1982. Hukum Perkawinan Islam dan Undang-Undang Perkawinan. Yogyakarta: Liberti.

Tim Penyusun Kamus Pusat Pembinaan dan Pengembangan Bahasa. 1990 Kamus Besar Bahasa Indonesia, Jakarta: Balai Pustaka

Winarno Surakhmad. 2005. Pengantar Penelitian Ilmiah, Bandung : Tarsito.

Zainuddin bin Abdul Aziz Al-Malibari Al-Fanani, Fath Al- Mu'in, Semarang: Toha Putra,tt

Zainudin Ali. 2006. Hukum Perdata Islam Di Indonesia. Jakarta: Sinar Grafika. 